\title{
INDICATIONS OF TESTICULAR BIOPSY IN STERILE MEN
}

\author{
JAN RABOCH AND ZD. ZÁHOǨ \\ Sexological Institute and Department of Pathology, \\ Charles University, Prague, Czechoslovakia
}

(Received 3rd Fanuary 1961)

Summary. The authors analyse some of the results of examination of 607 sterile patients, in which probatory excision from the testicles had been performed. They have reached the following conclusions.

Testicular biopsy is a decisive diagnostic method in the case of a repeated finding of azoospermia. In these cases, the following three conditions must be satisfied before probatory excision is carried out:

(1) The spermatic fluid must contain vesicular secretions.

(2) The long axis of the testes must be longer than $30 \mathrm{~mm}$.

(3) The patient must not have suffered from epididymitis of tuberculous origin.

In the cases of obstructive azoospermia, the authors recommend a careful evaluation of the germinal tissue before an eventual vasoepididymal anastomosis.

In cases of repeated findings of oligozoospermia gravis, they do not examine the germinal epithelium as in a majority of ninety-eight patients with this finding the state of germinal tissue was markedly deficient and not suitable for treatment.

From the therapeutic point of view, the authors exclude by means of testicular biopsy from long-term and expensive treatment those cases in which the histopathological picture in the testes does not justify any hope of a favourable result of therapy.

\section{INTRODUCTION}

The importance of the biopsy of testicles for the study and for the classification of their functional disturbances cannot be denied. On the other hand, opinions regarding the usefulness of probatory excision from male sexual glands, especially in cases of sterility, still differ widely. Although this problem has been the subject of several reports (Simmons, 1952; Payne \& Skeels, 1955; Getzoff, 1955, 1957; Weyeneth, 1958), we should like to endeavour, on the basis of an analysis of our findings and of our experiences, to define more exactly the cases in which we consider performance of the above-mentioned measure indicated. 


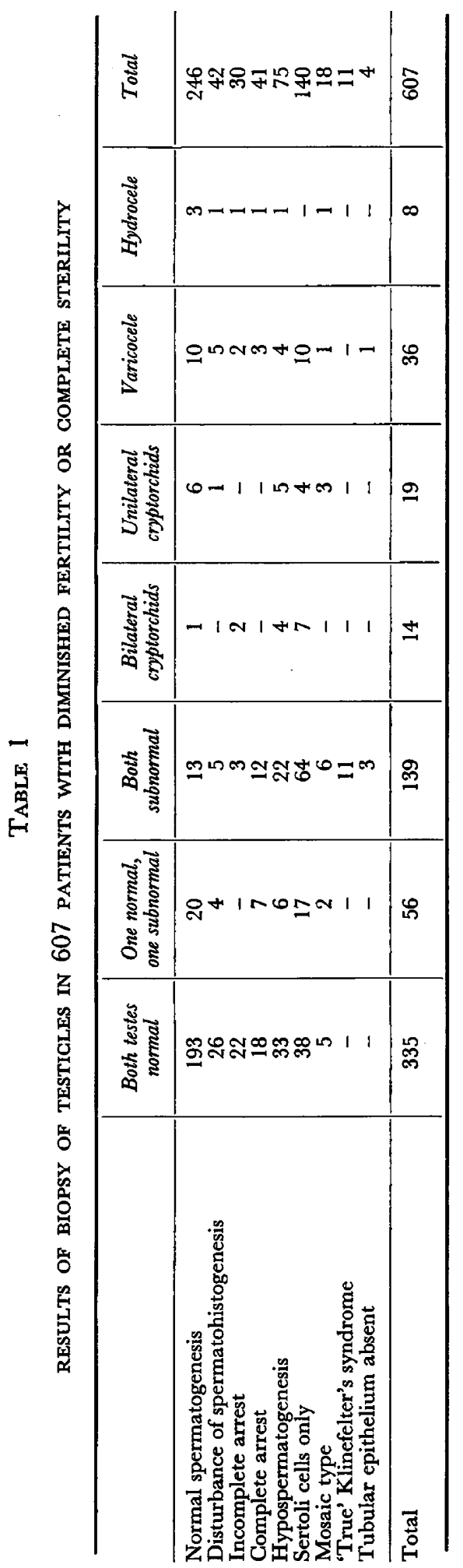




\section{MATERIAL AND METHODS}

In the course of 10 years, we have performed more than 700 probatory excisions. In 607 of these patients, the germinal tissue was examined for sterility, and the excised material could be precisely evaluated histologically.

All patients were examined clinically by the senior author. The long axis of the sexual glands was measured by means of the testimeter designed by Hynie. On the basis of the investigation of several thousands of patients we consider, as regards size, testes with the long axis shorter than $34 \mathrm{~mm}$ as subnormal (Raboch \& Záhoř, 1958; Raboch, 1961).

Probatory excision was performed with local anaesthesia on the upper third of the lateral surface of the testis, the incision being made transverse to the long axis of the organ (Harrison, 1952). The prolapsing parenchyma was immediately removed and fixed in Bouin's solution, embedded through chloroform into paraffin and stained with haematoxylin-eosin and Azan. The diameter of the tubules was objectively determined and the average value in individual cases calculated. All preparations were classified by the junior author. He based his classification (Záhor \& Raboch, 1958) chiefly on the state of the tubular epithelium, which, of all testicular components, shows the most numerous qualitative and quantitative changes.

In no cases was it necessary to admit the patient to the hospital. In some psychically more labile persons a slight collapse occurred but had no consequences. In two cases, a haematoma of the scrotum developed.

TABLE 2

THE HISTOPATHOLOGICAL PICTURE IN TESTIS BIOPSY MATERIAL FROM NINETY-EIGHT PATIENTS WITH OLIGOZOOSPERMIA GRAVIS

\begin{tabular}{l|c}
\hline \multicolumn{1}{c|}{ Histopathology } & No. cases \\
\hline Sertoli cells only & 29 \\
Hypospermatogenesis & 24 \\
Incomplete arrest & 20 \\
Disturbance of spermatohistogenesis & 10 \\
Mosaic type & 6 \\
Normal spermatogenesis & 4 \\
Complete arrest & 3 \\
'True' Klinefelter's syndrome & 1 \\
Tubular epithelium absent & 1 \\
\hline
\end{tabular}

\section{RESULTS}

The palpatory and histopathological findings in the cases of 607 bioptically examined men with reduced fertility or absolute sterility are given in Table 1 . It may be necessary to complement Table 1 with the following explanatory notes:

In cryptorchids with one undescended gland, we always examined the testis situated in the scrotum. In these cases, as well as in those with bilateral cryptorchidism, biopsy was carried out in adults. More detailed data have been published elsewhere (Raboch \& Záhoř, 1955, 1956; Záhoř \& Raboch, 1956). In a 
group of thirty-six patients with varicocele, probatory excision was performed eighteen times from the left testicle, sixteen times from the right, and twice from both glands. In each of eight men with hydrocele, we examined the affected gland, the excision being made in the course of the operation

According to our classification, a disturbance of spermatohistogenesis is said to exist when, despite a quantitatively more or less normal tubular epithelium, there is a disturbance in the transformation of spermatids into spermatozoa as shown by pyknosis of some spermatids and reduction in the number of spermatozoa, some of which have abnormally shaped heads.

Many authors consider a repeated finding of severe oligozoospermia (under 5 million spermatozoa per millilitre of ejaculate) as an indication for biopsy of the sex gland. We ourselves have investigated ninety-eight patients with this finding in the ejaculate, and the results are summarized in Table 2.

\section{DISGUSSION}

In the examination of sterile patients, probatory excision from the testes is a decisive diagnostic method in the case of repeated findings of azoospermia, when it is necessary to decide whether the absence of spermatozoa in the ejaculate is of testicular or of obstructive origin. Our decision to recommend the performance of a biopsy, which is rather unpleasant for the patient, depends on the following three conditions:

(1) The spermatic fluid must contain vesicular secretions. In their absence, which is attributable to agenesis of the ductus deferentes or to obliteration of the ductus ejaculatorii, biopsy is not performed.

(2) On the basis of experiences gained in the examination of the fertility of 500 men with hypoplastic testicles (Raboch, 1961), we do not recommend any biopsy of the germinal tissue in those patients where, in addition to an unfavourable finding in the ejaculate, the long axis of the testicles is shorter than $30 \mathrm{~mm}$. It is very unlikely that we should encounter such a state of the germinal epithelium that would justify any hope of its improvement through treatment.

(3) The patient must not have suffered from any epididymitis of tuberculous origin.

Biopsy of the testes is performed principally before vaso-epididymal anastomosis, even if the history and the palpatory finding on the testes and epididymides seem, in the given case, to indicate an obstructive origin of the sterility. The possibility of an unnecessary operation in men with complete arrest of spermatogenesis or with Sertoli cells only must be excluded through biopsy. We do not recommend vaso-epididymal anastomosis even if, in the case of obliteration, careful evaluation of the biopsy material reveals a less favourable state of germinal tissue, as, for example, in the case of hypospermatogenesis of a milder degree. The objective measuring of the average diameter of the seminiferous tubules (Záhor \& Raboch, 1958) is a valuable diagnostic tool for the evaluation of the state of the germinal epithelium.

We do not share the opinion of many authors that a repeated finding of oligozoospermia gravis is an indication for the performance of probatory 
excision, and that not even in the case of normal palpatory findings on the testes. The evaluation of the data given in Table 2 has shown that in a majority of our cases the histopathological pictures in the germinal glands did not justify any hope of successful treatment. By performing the biopsy the physician will, in a majority of these cases, only find confirmation of the fact that the state of the germinal epithelium is markedly deficient and unsuitable for treatment.

From the therapeutic point of view, biopsy may be considered desirable in the cases of patients in which palpatory examination does not reveal any more marked deviations of the genitals, and in which the findings in the ejaculate are better than severe oligozoospermia. We share Charny's (1959) opinion that before the introduction of long-term treatment it is necessary to follow the routine of biopsy examination. A favourable therapeutic result may be expected only in the case of a finding of adequately developed tubules with an average diameter of at least $150 \mu$, without distinct changes on the walls and in the intertubular tissue, and with a not too unfavourable picture of the germinal epithelium, e.g. in cases of mild hypospermatogenesis or incomplete arrest.

After 10 years' experience with testicular biopsy, we are of the opinion that this investigation should be in each case indicated by a physician with ample experience in these matters. Co-operation with a pathologist capable of accurate evaluation also of minor changes in the histopathological picture is essential.

\section{REFERENCES}

Gharny, Ch. W. (1959) The use of androgens for human spermatogenesis. Fertil. \& Steril. 10, 557.

GETZOFF, P. L. (1955) Clinical evaluation of testicular biopsy and the rebound phenomenon. Fertil. $\mathbb{E}$ Steril. 6, 465.

Getzoff, P. L. (1957) Testicular biopsy in male infertility. Int. J. Fertil. 2, 243.

Harrison, R. G. (1952) Functional importance of the vascularization of the testis and epididymis for the maintenance of normal spermatogenesis. Fertil. Eै Steril. 3, 366.

PAyne, S. \& Skeets, R. F. (1955) Testicular biopsy: which infertile patients are benefited? Fertil. \& Steril. 6, 43.

RAвоch, J. (1961) Hypoplasie varlat. Thomayerova sbirka, p. 403. Státni zdravotnicke nakladatelstvi, Prague.

RABOch, J. \& ZÁHoR̆, Z. (1955) Über die Fertilität von Männern mit Kryptorchismus. Schweiz. med. Wschr. 85, 1196.

RABOCH, J. \& ZÁHOř, Z. (1956) Ein Beitrag zum Studium der inkretorischen Hodenfunktion bei Kryptorchismus. Endokrinologie, 33, 160.

RAвосн, J. \& ZÁHớ, Z. (1958) The fertility of men with hypoplastic testicles. Proc. IInd World Congr. Fertil. Steril. 2, 670 .

Srmmons, F. A. (1952) Correlation of testicular biopsy material with semen analysis in male infertility. Ann. N.Y. Acad. Sci. 55, 643.

Weyeneth, R. (1958) La valeur de la biopsie des testicules dans le diagnostic de la stérilité masculine et dans l'indication thérapeutique. Proc. IInd World Congr. Fertil. Steril. 2, 682.

ZÁHở, Z. \& RABOCH, J. (1956) Ein Beitrag zum Problem der Hodenbiopsie bei Kryptorchismus unter besonderer Berücksichtigung des Optimalalters für die Orchidopexie. Schweiz. med. Wschr. 86, 311.

ZÁHoŕ, Z. \& RABOCH, J. (1958) Experiences with the evaluation of about 400 testicular biopsies. Proc. IInd World Congr. Fertil. Steril. 2, 661. 